\title{
Kemampuan Daya Serap Zeolit Sintetis Dibandingkan dengan Serpentin Teraktifasi Terhadap Gas $\mathrm{CO}_{2}$
}

\author{
M. LUTFI, HARRY TETRA ANTONO, AGUS WAHYUDI, RETNO DAMAYANTI \\ Puslitbang Teknologi Mineral dan Batubara \\ Jl. Jenderal Sudirman 623 Bandung \\ Telp. (022) 6030483, Fax. (022) 6003373 \\ Email: lutfi@tekmira.esdm.go.id
}

\begin{abstract}
ABSTRAK
Kebutuhan energi yang semakin meningkat merupakan salah satu penyebab peningkatan konsentrasi $\mathrm{CO} 2$ di atmosfir. Penelitian tentang penangkapan $\mathrm{CO} 2$ telah banyak dilakukan, beberapa material dapat dipakai sebagai adsorben $\mathrm{CO} 2$. Kegiatan yang dilakukan meliputi pembuatan bahan penyerap yang berasal dari beberapa material/mineral, yaitu zeolit sintetik dan aktivasi serpentin; perancangan alat simulasi dan uji coba penyerapan $\mathrm{CO} 2$. Kedua material tersebut kemudian diujikan sebagai material penyerap/adsorben gas $\mathrm{CO} 2$ pada alat simulasi penyerapan $\mathrm{CO} 2$. Hasil serapan tertinggi gas $\mathrm{CO} 2$ menggunakan zeolit sintetik adalah $13.98 \%$ (3.92 g/g) dengan jumlah zeolit yang digunakan sebesar $5 \mathrm{~g}$, sedangkan bila menggunakan serpentin teraktivasi adalah $14.3 \%(5.13 \mathrm{~g} / \mathrm{g})$ dengan jumlah serpentin yang digunakan sebesar $5 \mathrm{~g}$, keduanya dapat digunakan sebagai bahan penyerap $\mathrm{CO} 2$.

Kata Kunci: Zeolit Sintetis (NaX), Serpentin, adsorben CO2, kapasitas adsorpsi.
\end{abstract}

\begin{abstract}
The increase of energy requirement is one of the causes of the increase in the concentration $\mathrm{CO} 2$ in the atmosphere. The research on capturing $\mathrm{CO} 2$ has been carried out, several materials could be used as adsorben $\mathrm{CO} 2$. The activities that were carried out covered the production of the absorbent material by using several materials/minerals, those are synthetic zeolite and activated serpentine; simulation instrument design and the absorption test of $\mathrm{CO} 2$. Both materials were then tested for adsorbing $\mathrm{CO} 2$ gas using inframent. High Results of the absorption test show that synthetic zoelit and activated Serpentin of $5 \mathrm{~g}$ could adsorp CO2 gas $13.98 \%(3.92 \mathrm{~g} / \mathrm{g})$ and $14.3 \%(5.13 \mathrm{~g} / \mathrm{g})$ respectively, so both of them could be used as absorbent material for $\mathrm{CO} 2$ gas.

Keywords: Synthetic Zeolite (NaX), Serpentine, adsorbent CO2, capacity of adsorpsion.
\end{abstract}

\section{LATAR BELAKANG}

Proses melepaskan karbondioksida ke udara yang selanjutnya terakumulasi di atmosfer akibat pembakaran bahan bakar fosil telah berlangsung sejak dulu. Hal ini terjadi di hampir seluruh belahan bumi, termasuk di Indonesia sebagaimana terlihat dari komposisi bauran energi nasional yang hingga tahun 2030 masih menggantungkan pada penggunaan batubara dan BBM (Gambar 1). 


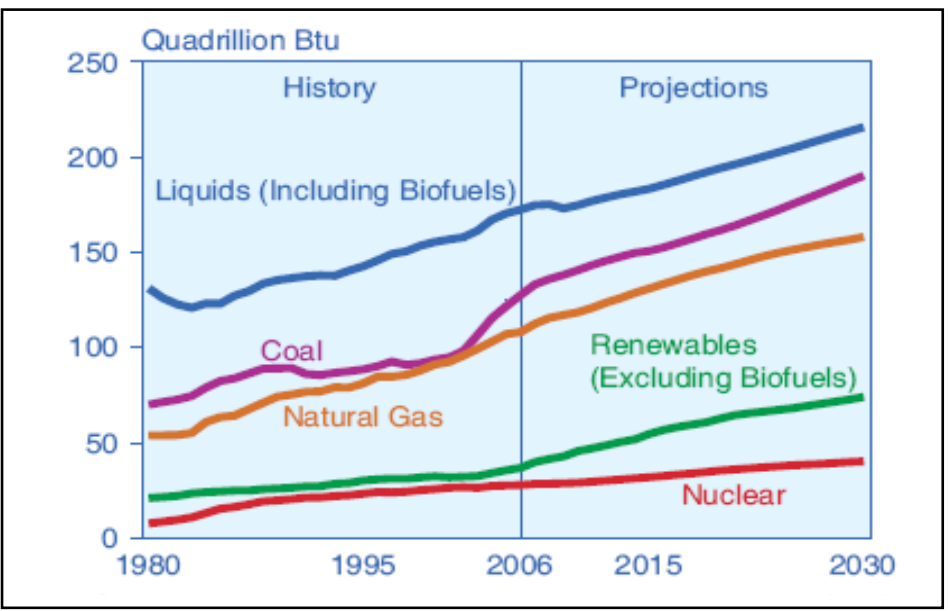

Gambar 1. Penggunaan Energi Dunia Berdasarkan Jenis Bahan Bakar

Berkaitan dengan hal di atas perlu dilakukan langkah-langkah rasional dalam rangka mitigasi terhadap perubahan iklim, yaitu tindakan yang diperlukan untuk mengurangi emisi gas rumah kaca dan memperbesar potensi penyerapan karbon dalam pencegahan pemanasan global.

Pada umumnya, proyek percontohan penangkapan karbon dilakukan melalui post-combustion, karena teknologi ini merupakan teknologi yang telah mapan pada proses penangkapan karbon.

Karakter sorben yang dibutuhkan adalah yang memiliki kapasitas adsorpsi $\mathrm{CO}_{2}$ yang tinggi, dan memiliki stabilitas kimia dan mekanik untuk periode operasi yang lama dalam siklus berulang. Untuk itu maka mulai tahun 2010, Puslitbang Teknologi Mineral dan Batubara melakukan kegiatan untuk penguasaan teknologi penangkapan $\mathrm{CO}_{2}$ dengan cara mengembangkan material penyerap $\mathrm{CO}_{2}$ yang merupakan langkah awal untuk menerapkan teknologi penangkapan $\mathrm{CO}_{2}$ pada industri berbahan bakar batubara di Indonesia.

\section{TINJAUAN PUSTAKA}

\section{Penggunaan Zeolit Sintetis sebagai Penyerap Gas $\mathrm{CO}_{2}$}

Proses adsorpsi pada teknologi post-combustion penangkapan $\mathrm{CO}_{2}$ menggunakan molecular sieves atau karbon aktif sebagai adsorben. Menurut Yokoyama (2003), adsorben yang dapat digunakan adalah zeolit X. Hasil uji pilot pemulihan $\mathrm{CO}_{2}$ dari gas buang pembakaran batubara oleh proses adsorpsi menunjukkan bahwa kemurnian $\mathrm{CO}_{2}$ yang dipulihkan adalah sekitar 99,0\%-volum dengan menggunakan sistem PSA (Pressure Swing Adsorption) dan PTSA (Pressure Temperature Swing Adsorption) dua tahap (Ishibashi et al., 1999). Berdasarkan pemodelan matematika, dan data dari instalasi percobaan skala pilot, rancangan proses lengkap skala industri layak digunakan. Kelemahan metoda adsorpsi adalah diperlukannya pengolahan gas umpan sebelum pemisahan $\mathrm{CO}_{2}$ di dalam adsorber. Operasi pada temperatur tinggi dengan sorben lainnya dapat menghindari kebutuhan ini (Sircar dan Golden, 2001). Dalam banyak kasus, gas perlu didinginkan dan dikeringkan yang membatasi daya tarik PSA, TSA ataupun ESA (Electric Swing Adsorption) bila dibandingkan dengan proses absorpsi kimia. Pengembangan bahan generasi baru yang dapat mengadsorpsi $\mathrm{CO}_{2}$ secara efisien akan meningkatkan daya saing penggunaan metode adsorpsi dalam aplikasi gas buang.

Bahan lainnya yang dapat digunakan dalam pemisahan $\mathrm{CO}_{2}$ pada temperatur tinggi adalah membran ataupun oksida logam, seperti: $\mathrm{CaO}$. Sorben padatan yang sedang diteliti untuk penangkapan $\mathrm{CO}_{2}$ pada skala besar adalah oksida sodium ataupun potassium, dan karbonat (untuk memproduksi bikarbonat), biasanya disangga pada substrat padatan (Hoffman et al., 2002; Green et al., 2002). Selain itu, sorben berbasis Li ataupun berbasis CaO pada temperatur tinggi merupakan kandidat yang tepat. Penggunaan senyawa yang mengandung litium (oksida litium, litium-zirkonia, ataupun litium silika) dalam siklus karbonasi-kalsinasi, pertama kali diinvestigasi di Jepang (Nakagawa dan Ohashi, 1998). Kinerja sorben ini sangat 
baik, dengan reaktivitas yang sangat tinggi dalam rentang temperatur yang lebar di bawah $700^{\circ}$ $\mathrm{C}$, regenerasi yang cepat pada temperatur yang lebih tinggi dan daya tahan dalam siklus berulang penangkapan-regenerasi.

Kelakuan adsorpsi $\mathrm{CO}_{2}$ dari beberapa kelas adsorben $\mathrm{CO}_{2}$ padatan yang berbeda, termasuk zeolit, karbon aktif, kalsium oksida, hidrotalsit, hibrida organik-anorganik, dan kerangka logam-organik (Sunho Choi et al., 2009).

Penelitan Tezel mengenai kemampuan beberapa zeolit sintetik yaitu 13X, NaY, HiSiv-1000 ( zeolit komersial NaY dengan rasio $\mathrm{SiO}_{2} / \mathrm{Al}_{2} \mathrm{O}_{3}>20$ ), HY-5, ZSM-5-30 (MFI) dan HiSiv-3000 (zeolit komersial berdasarkan pada struktur ZSM-5 dengan rasio $\mathrm{SiO}_{2} / \mathrm{Al}_{2} \mathrm{O}_{3}>1000$ ). Isotermal adsorpsi komponen $\mathrm{CO} 2$ murni pada zeolit ini memperlihatkan range kapasitas adsorpsi yang lebar dari 1,2 mmol per gram adsorben (HY-5) hingga 4,5 mmol per gram (13X) pada $295 \mathrm{~K}$ dan tekanan 1 bar.

Siriwardane juga melakukan penelitian mengenai kemampuan adsorpsi CO2 dari zeolit alam chabazite (CHA) dan Clinoptilolite (HEULANDITE) hingga tekanan setinggi 20 bar dan dari isotermal adsorpsi terlihat bahwa terjadi peningkatan kapasitas adsorpsi CO2 dengan tekanan hingga 1 bar dan diikuti oleh kapasitas adsorpsi yang berangsur angsur linier hingga tekanan maksimum studi. Sifat adsorpsi $\mathrm{CO} 2$ pada zeolit pada kondisi tekanan tinggi juga diinvestigasi oleh Rodrigues dimana kapasitas adsorpsi CO2 zeolit 13X dievaluasi pada tekanan hingga 50 bar pada tiga suhu yang berbeda seperti tampak pada Gambar 2.

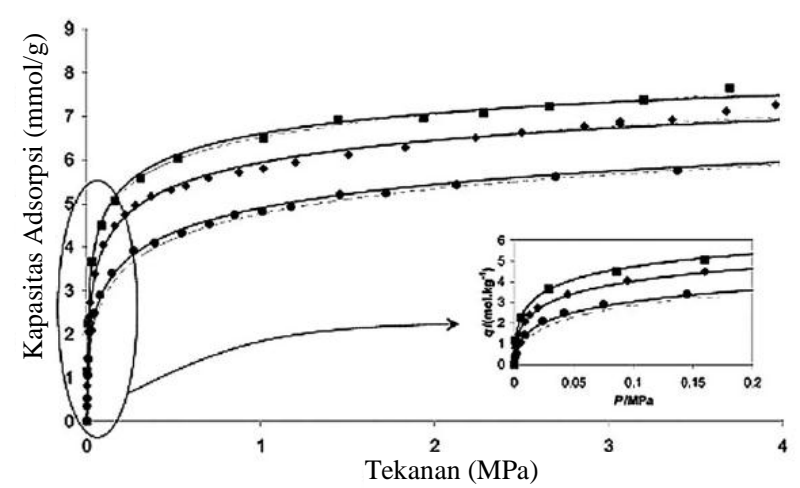

Gambar 2. Isotermal Adsorpsi $\mathrm{CO}_{2}$ Zeolit $13 \mathrm{X}$

: T=298 K $,: \mathrm{T}=308 \mathrm{~K}, \mathbf{T}: \mathrm{T}=323 \mathrm{~K}$, garis padat adalah Model Toth, garis putus-putus adalah model multisite Langmuir

Isotermal zeolit 13X pada 293, 308 dan $323 \mathrm{~K}$ memperlihatkan adsorpsi $\mathrm{CO}_{2}$ pada tekanan yang diberikan menurun secara signifikan akibat adanya sedikit kenaikan suhu. Kapasitas adsorpsi $13 \mathrm{X}$ terhadap $\mathrm{CO}_{2}$ meningkat perlahan dengan naiknya tekanan (Rosa, dkk. 2011).

\section{Penggunaan Serpentin sebagai Penyerap Gas $\mathrm{CO}_{2}$}

Batuan serpentin merupakan batuan metamorf yang terbentuk dari mineral serpentin akibat perubahan basalt dasar laut yang bertekanan tinggi pada temperatur rendah. Mineral serpentin tergolong dalam kelas mineral silikat yaitu Phyllosilicates. Batuan Serpentin sering digunakan untuk batu hias dan dipakai untuk industri mineral. Mineral Serpentin mengandung chrysotile yaitu mineral serpentin yang mengkristal membentuk serat tipis yang panjang. Mineral serpentin memiliki beberapa senyawa kimia antara lain Antigorite; $\left[(\mathrm{Mg}, \mathrm{Fe})_{3} \mathrm{Si}_{2} \mathrm{O}_{5}(\mathrm{OH})_{4}\right]$, Clinochrysotile $\left[\mathrm{Mg}_{3} \mathrm{Si}_{2} \mathrm{O}_{5}(\mathrm{OH})_{4}\right]$, Lizardite $\left[\mathrm{Mg}_{3} \mathrm{Si}_{2} \mathrm{O}_{5}(\mathrm{OH})_{4}\right]$, Orthochrysotile $\left[\mathrm{Mg}_{3} \mathrm{Si}_{2} \mathrm{O}_{5}(\mathrm{OH})_{4}\right]$, Parachrysotile $\left[(\mathrm{Mg}, \mathrm{Fe})_{3} \mathrm{Si}_{2} \mathrm{O}_{5}(\mathrm{OH})_{4}\right]$.. Perbandingan karakteristik berbagai mineral tersebut yang ditampilkan oleh FT-Raman spectroscopy tersaji dalam Gambar 3. 


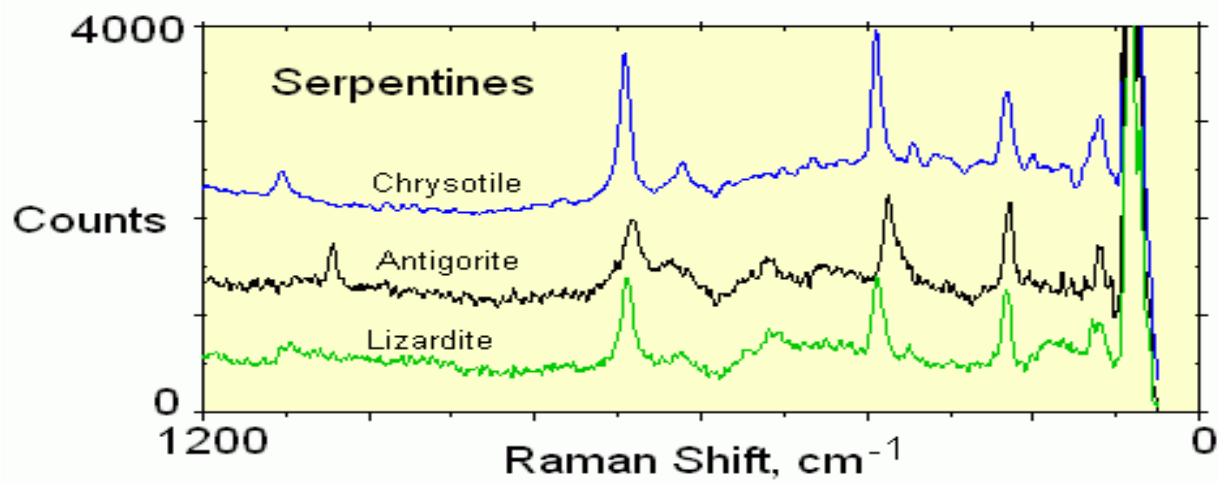

Gambar 3. Karakteristik serpentin. (Rinaudo., et. al., 2003)

Karakteristik batu serpentin adalah berwarna hijau kehitaman, cokelat, merah dan hitam, kekerasan antara 2,5-5, bentuk kristal ortorombik, monoklin, dan heksagonal, ortorombik, monoklin, dan heksagonal, berat jenis 2,5-2,6.

Mineral serpentin dapat digunakan sebagai bahan alternatif penyerap gas $\mathrm{CO}_{2}$. Metode penyerapan ini diharapkan dapat menurunkan emisi gas $\mathrm{CO}_{2}$ sehingga dapat menurunkan terjadinya pemanasan global sebagai pemicu fenomena perubahan iklim. Skema penyerapan karbonnya tersaji dalam Gambar 4.

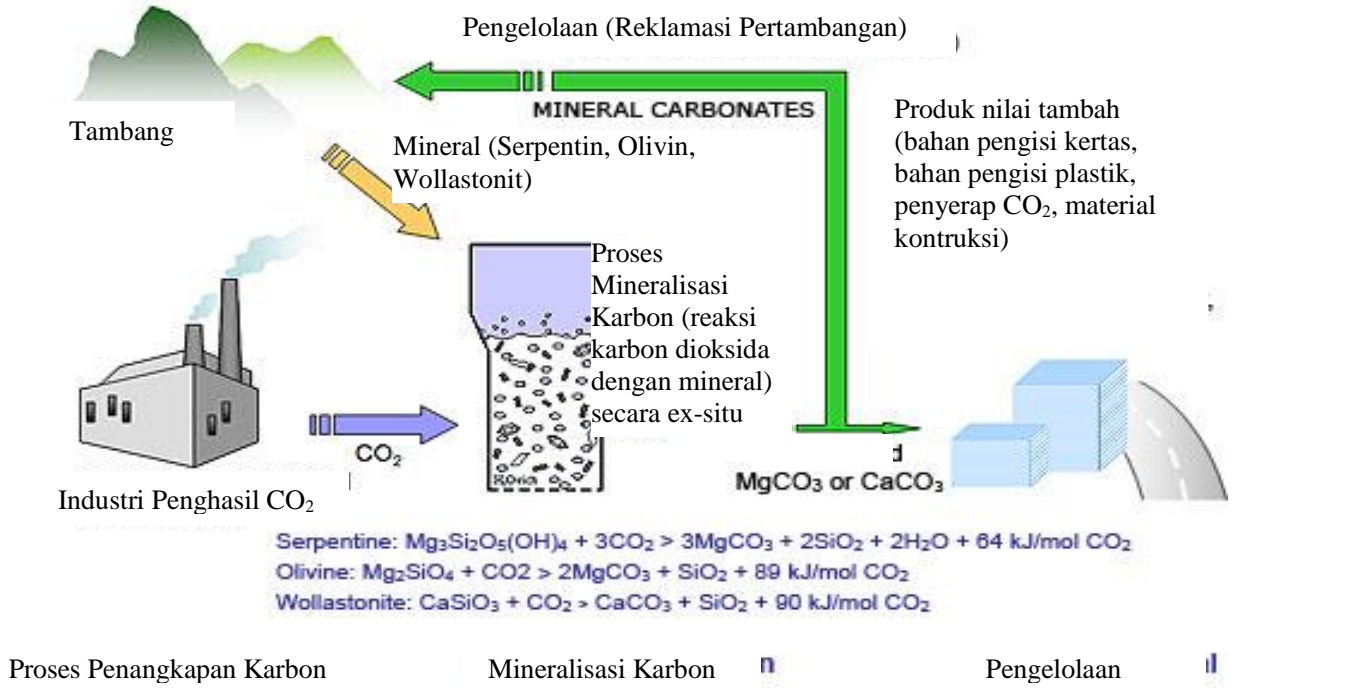

Gambar 4. Skema penyerapan karbon. (Park dan Fan, 2004)

Reaksi yang terjadi pada proses diatas adalah sebagai berikut:

$$
\mathrm{Mg}_{3} \mathrm{Si}_{2} \mathrm{O}_{5}(\mathrm{OH})_{4}+3 \mathrm{CO}_{2} \rightarrow 3 \mathrm{MgCO}_{3}+2 \mathrm{SiO}_{2}+2 \mathrm{H}_{2} \mathrm{O}
$$

Menurut Mc Kelvy., et., al 2001 dalam Huijgen dan Comans , 2003, energi kinetika reaksinya terdiri dari 2 tahap, yaitu:

Tahap $1: \mathrm{Mg}(\mathrm{OH})_{2} \rightarrow \mathrm{MgO}+\mathrm{H}_{2} \mathrm{O}$ (dehidroksinasi)

Tahap $2: \mathrm{MgO}+\mathrm{CO}_{2} \rightarrow \mathrm{MgCO}_{3}$ (karbonasi)

Reaksi tahap pertama merupakan suatu reaksi yang dapat bolak-balik, sehingga persamaannya menjadi:

$$
\mathrm{MgO}+\mathrm{H}_{2} \mathrm{O} \rightarrow \mathrm{Mg}(\mathrm{OH})_{2} \text { (rehidroksilasi) }
$$


Serpentin harus diaktifasi terlebih dahulu, agar dapat digunakan sebagai bahan penyerap gas $\mathrm{CO}_{2}$. Terdapat berbagai macam metode aktifasi yang dapat dilakukan. Pertama melalui proses fisika. Proses ini dilakukan dengan memanaskan serpentin di dalam tungku pada suhu $650^{\circ} \mathrm{C}$ selama 3 jam. Metode aktifasi serpentin yang kedua adalah secara kimia. Melalui metode ini serpentin direaksikan dengan beberapa zat kimia seperti asam klorida ( $\mathrm{HCl}$ ), asam sulfat $\left(\mathrm{H}_{2} \mathrm{SO}_{4}\right)$, asam fosfat $\left(\mathrm{H}_{3} \mathrm{PO}_{4}\right)$ dan asam asetat $\left(\mathrm{CH}_{3} \mathrm{COOH}\right)$. Proses aktifasi dilakukan dengan mereaksikan asam klorida, asam sulfat dan asam fosfat dengan serpentin pada suhu $150^{\circ} \mathrm{C}$ selama 1 jam. Selanjutnya serpentin tersebut didinginkan dan direaksikan dengan asam asetat pada suhu kamar selama 24 jam. Kondisi terakhir serpentin adalah bersuasana basa $(\mathrm{NaOH})$ (Maroto., et. al., 2004). Hasil penelitiannya menunjukkan bahwa proses kimia tidak efektif menghilangkan kadar air (moisture content) serpentin dibandingkan dengan proses aktivasi secara fisika. Selisih efektifitasnya mencapai $11 \%$. Namun aktivasi secara proses kimia dapat efektif meningkatkan kadar MgO lebih tinggi dibandingkan dengan proses fisika.

Sementara Yoo., et.al., 2009 mengemukakan bahwa serpentin dapat diaktifasi hanya dengan menggunakan asam sulfat $\left(\mathrm{H}_{2} \mathrm{SO}_{4}\right)$. Diungkapkan bahwa serpentin dapat menjadi aktif dengan mereaksikan bahan tersebut dengan asam sulfat $0,5 \mathrm{M}$ pada suhu $90^{\circ} \mathrm{C}$ selama 30 menit. Energi aktifasinya mencapai $82 \mathrm{~kJ} / \mathrm{mol}$.

Hasil penelitian Park dan Fan, 2004, lebih memperjelas lagi tentang proses aktifasi serpentin. Proses aktifasi sebenarnya adalah menghilangkan $\mathrm{SiO}_{2}$ yang melekat di permukaan serpentin. $\mathrm{SiO}_{2}$ merupakan penghalang terjadinya reaksi antara $\mathrm{MgO}$ dengan gas $\mathrm{CO}_{2}$. Untuk menghilangkan $\mathrm{SiO}_{2}$ pada serpentin, digunakanlah asam klorida $(\mathrm{HCl})$. Serpentin direndam dalam larutan asam klorida berkonsentrasi $1 \mathrm{M}$ selama 5 jam pada suhu $70^{\circ} \mathrm{C}$ dan bertekanan ruangan (1 atm). Dengan proses pelindian ini sekitar 40\% MgO dapat dihasilkan. Konsentrasi slurrynya berkisar 2,5 g/80 ml yang sangat cocok digunakan sebagai bahan penyerap gas $\mathrm{CO}_{2}$. Untuk menambah daya serap serpentin, ditambahkanlah ammonium hidroksida $\left(\mathrm{NH}_{4} \mathrm{OH}\right)$ hingga $\mathrm{pH}$ nya mencapai 10. Prosesnya tampak pada Gambar 5. Reaksi yang terjadi pada proses ini adalah sebagai berikut :

$$
\mathrm{Mg}_{3} \mathrm{Si}_{2} \mathrm{O}_{5}(\mathrm{OH})_{4}+6 \mathrm{H}^{+} \rightarrow 3 \mathrm{Mg}^{2+}+2 \mathrm{Si}(\mathrm{OH})_{4}+\mathrm{H}_{2} \mathrm{O}
$$

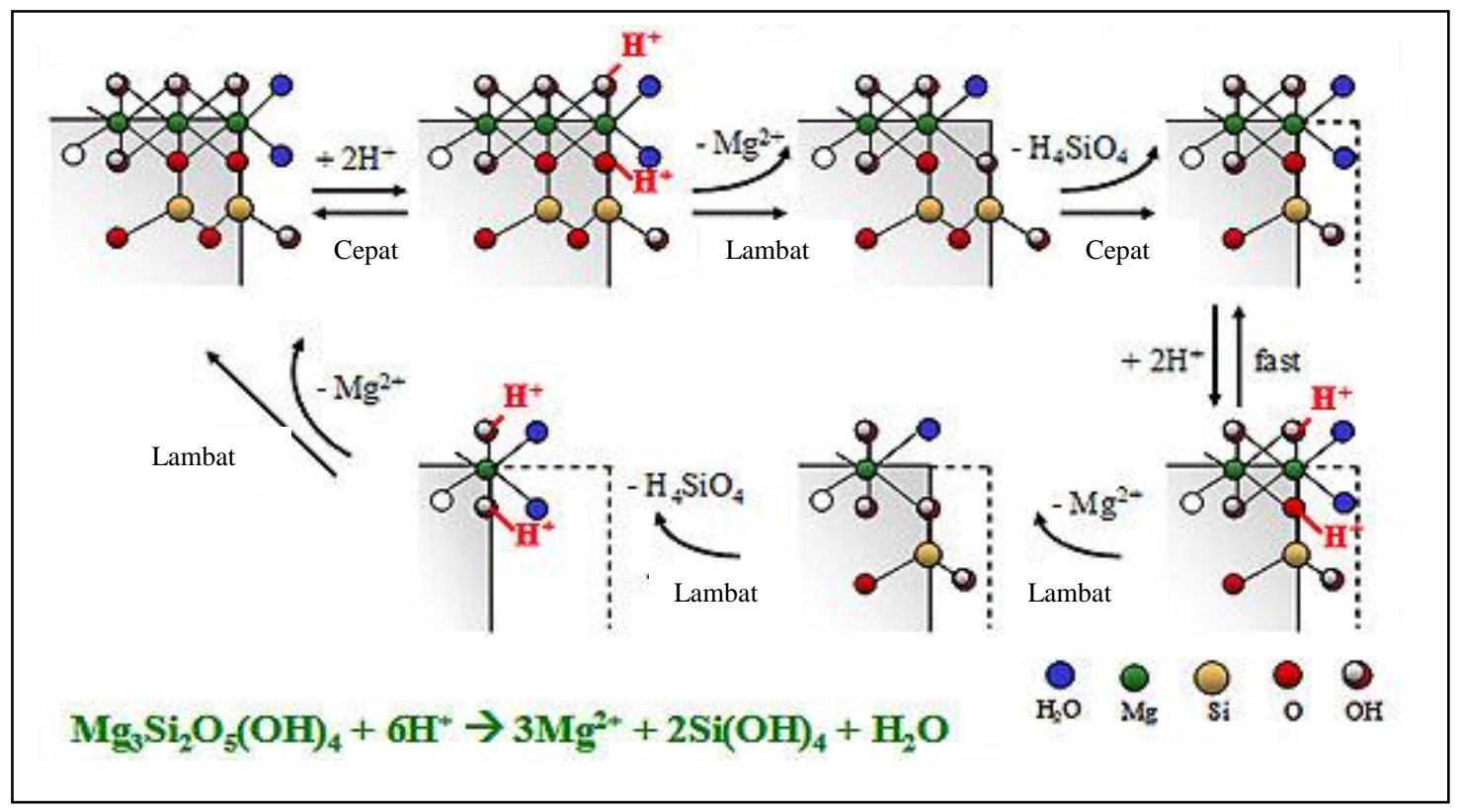

Gambar 5. Mekanisme pelarutan serpentin (Park dan Fan, 2004) 


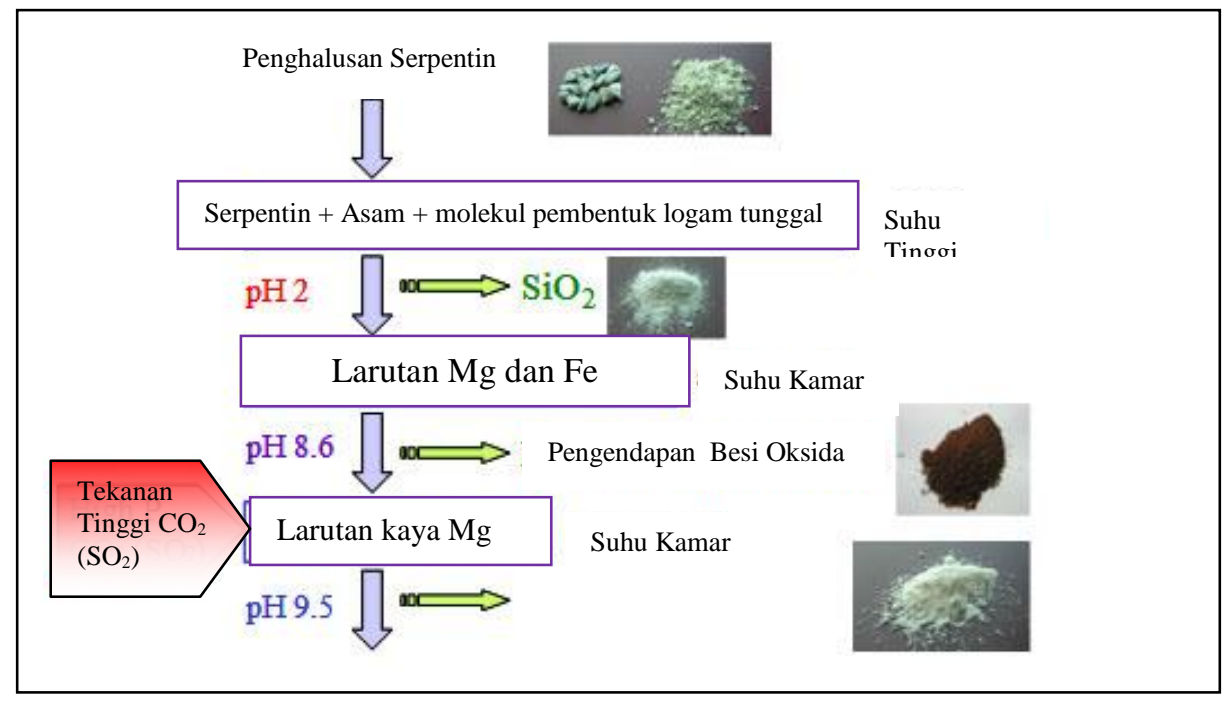

Gambar 6. Proses penyesuaian pH (Park dan Fan, 2004)

Kajian secara mendalam mengenai penggunaan serpentin sebagai bahan penyerap gas $\mathrm{CO}_{2} \mathrm{di}$ Finlandia (Zevenhoven dan Kohlmann, 2001) telah dilakukan. Salah satu kajiannya adalah di pembangkit listrik Salmisaari. Hasil kajiannya menunjukkan bahwa untuk menangkap gas $\mathrm{CO}_{2}$ dibutuhkan serpentin sebanyak 2,1 Metrik ton $(1000 \mathrm{~kg})$ setiap tahunnya. Agar efisiensi penyerapan mencapai $100 \%$, maka dibutuhkan mineral serpentin sekitar 2,18 Metrik ton (1000 $\mathrm{kg})$. Sementara untuk mereduksi $5 \%$ gas $\mathrm{CO}_{2}$, dibutuhkan sekitar 6,11 Metrik ton (1000 kg) serpentin. Setiap ton $\mathrm{CO}_{2}$ akan menghasilkan 0,66 ton silika, 1,92 ton magnesium karbonat, dan setiap 1 ton serpentin dapat menghasilkan 1,2 ton produk padatan.

\section{METODOLOGI}

Kegiatan penelitian yang dilakukan terdiri dari pembuatan zeolit sintetis dan aktifasi serpentin, uji coba adsorpsi $\mathrm{CO}_{2}$, modifikasi alat pengurang $\mathrm{CO}_{2}$ dengan penambahan oven pada keluaran gas $\mathrm{CO}_{2}$ sintetis dan karakterisasi adsorben yang dijelaskan dalam tabel berikut.

Tabel 1. Karakterisasi Mineral Serpentin

\begin{tabular}{|l|l|}
\hline Rumus Kimia & $\mathrm{Mg}_{6}\left(\mathrm{Si}_{4} \mathrm{O}_{10}\right)(\mathrm{OH})_{8}$ \\
\hline Berat Jenis $\left(\mathrm{g} / \mathrm{cm}^{3}\right)$ & $2.7-2.8$ \\
\hline Sistem Kristal & $\begin{array}{l}\text { Orthorombik, Monoklin dan } \\
\text { Heksagonal }\end{array}$ \\
\hline Warna & $\begin{array}{l}\text { Hijau kehitaman, Coklat, Merah } \\
\text { dan Hitam }\end{array}$ \\
\hline Goresan & Putih \\
\hline Kekerasan (mohs) & $3.5-4$ \\
\hline
\end{tabular}


Tabel 2. Karakteristik Zeolit NaX

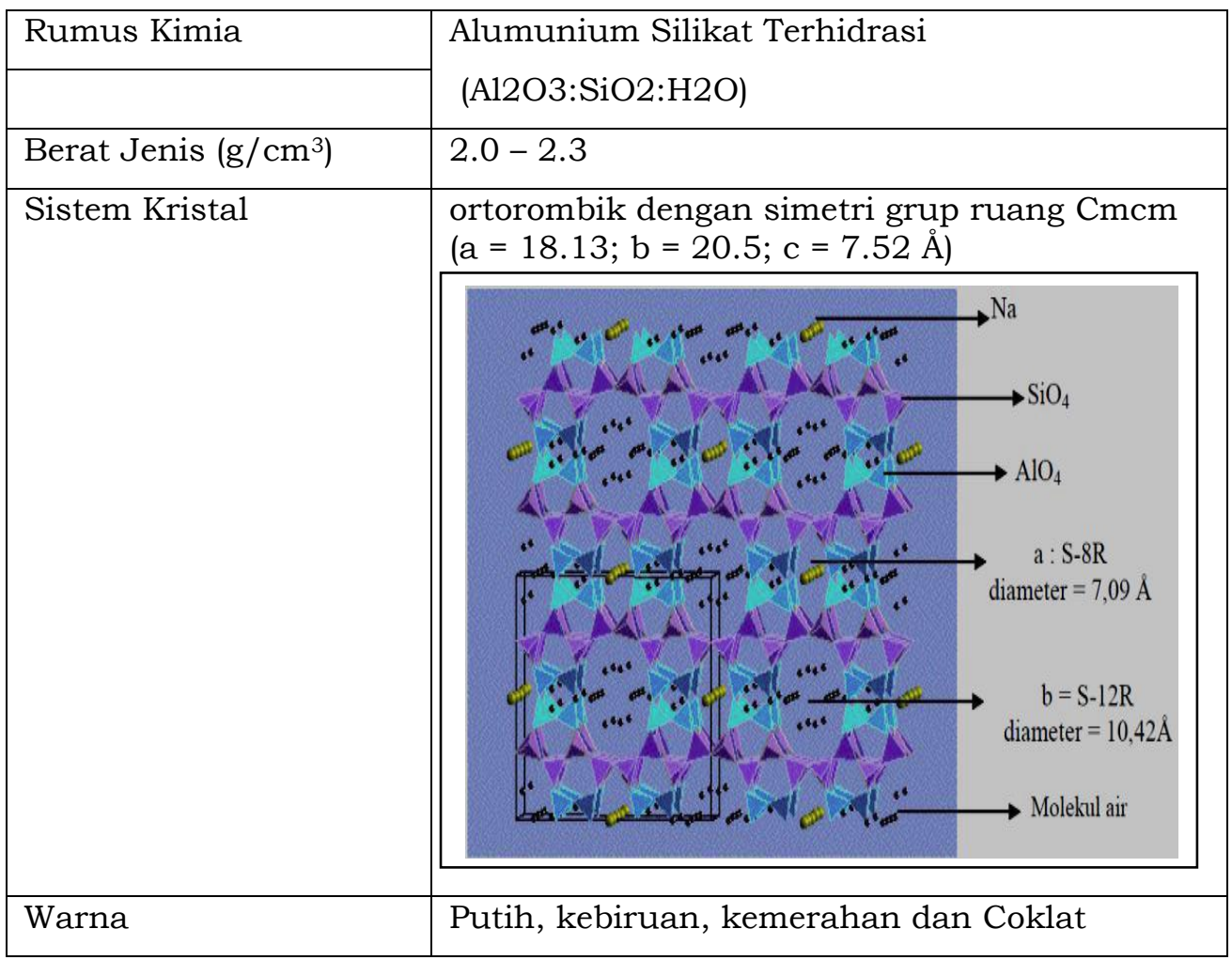

Sedangkan zeolit sintetis memiliki sifat yang lebih baik dibanding dengan zeolit alam, Perbedaan terbesar antara zeolit sintetis dengan zeolit alam adalah :

1. Zeolit sintetis dibuat dari bahan kimia dan bahan-bahan alam

2. Zeolit sintetis memiliki perbandingan silika dan alumina yaitu 1:1 sedangkan pada zeolit alam hingga 5:1

3. Zeolit alam tidak terpisah dalam lingkungan asam seperti halnya zeolit sintetis.

(Rodhie Saputra, Pemanfaatan zeolit sintetis)

Pengembangan adsorben menggunakan zeolit sintetis dan serpentin. Karakterisasi adsorben meliputi analisis luas permukaan, $\mathrm{XRD}$, dan TGA. Alat pengurang $\mathrm{CO}_{2}$ dirakit berdasarkan teknik fluidisasi. Adapun pengukuran $\mathrm{CO}_{2}$ dari gas buang memakai alat flue gas analyzer. 


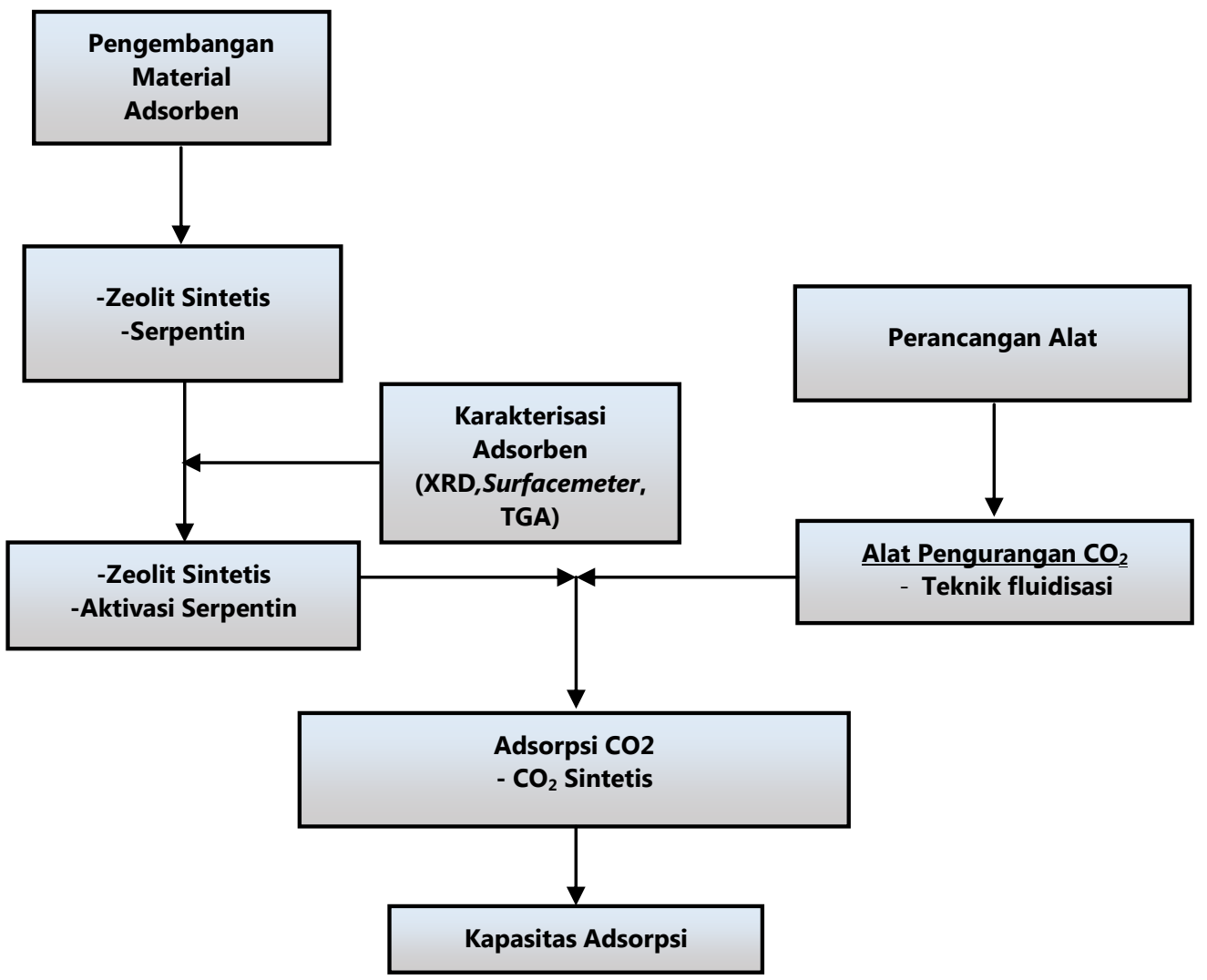

Gambar 7. Alur Proses Percobaan Adsorpsi $\mathrm{CO}_{2}$

\section{HASIL DAN PEMBAHASAN}

Uji coba adsorpsi dilakukan dengan gas $\mathrm{CO}_{2}$ sintetis dengan kisaran konsentrasi $\mathrm{CO}_{2}$ 8-15\% (sisanya $\mathrm{N}_{2}$ ) dan gas buang hasil pembakaran batubara. Variabel berubah pada penelitian ini adalah berat adsorben dan interval waktu adsorpsi. Pembacaan pengukuran dihentikan ketika nilai adsorpsi telah konstan yang menandakan kapasitas adsorpsi telah maksimal. Beberapa kondisi hasil adsorpsi tampak pada Gambar 8 berikut: 


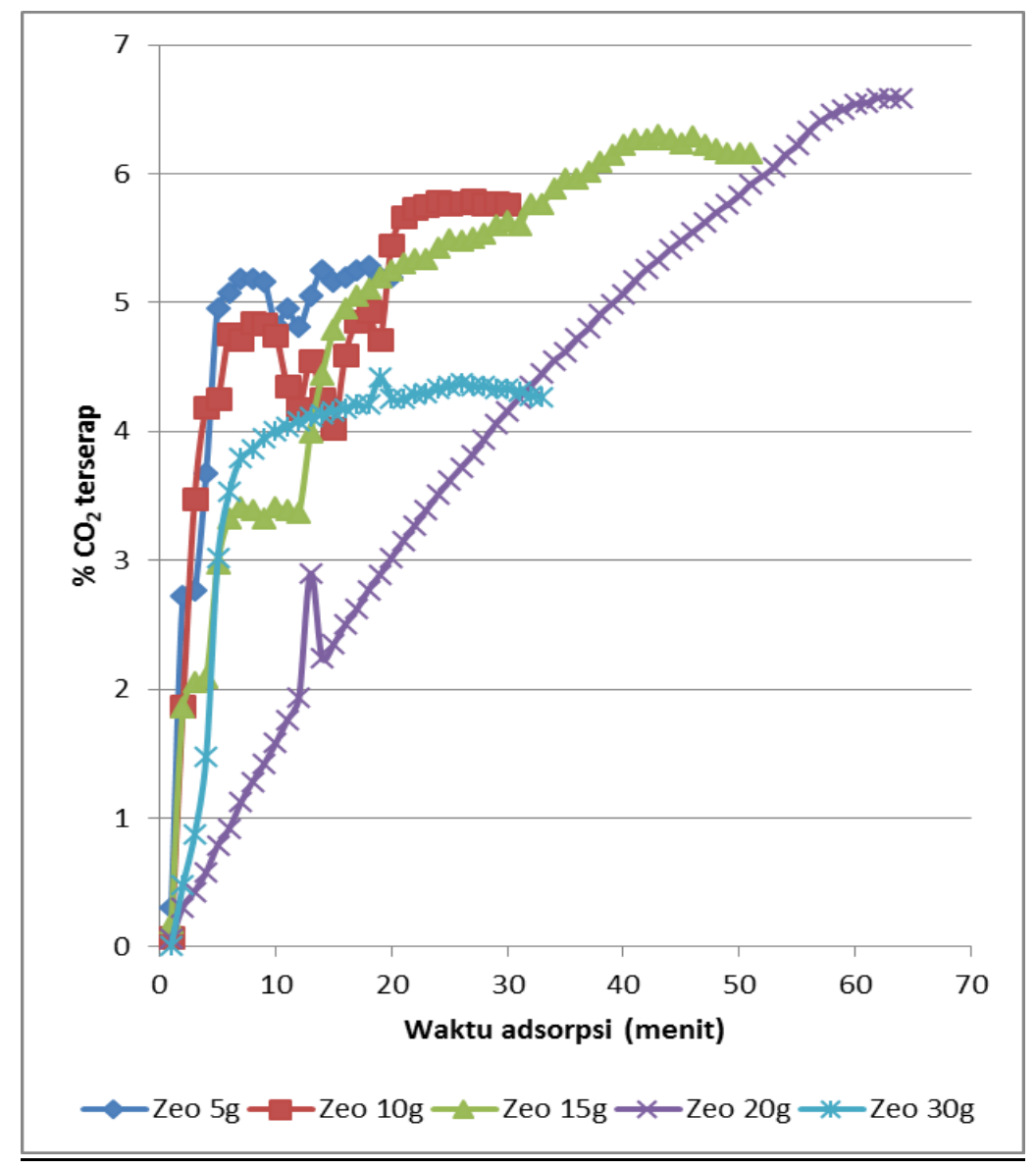

Gambar 8. Hasil adsorpsi gas $\mathrm{CO}_{2}$ menggunakan adsorben zeolit $\mathrm{X}$ pada beberapa variasi berat adsorben (interval adsorpsi tiap 1 menit)

Pada adsorben zeolit $5 \mathrm{~g}$ tampak waktu untuk mencapai konstan sekitar 20 menit dengan kapasitas adsorpsi sebesar 5,2\%. Sedangkan untuk zeolit $10 \mathrm{~g}$ dibutuhkan waktu sekitar 30 menit dengan kapasitas adsorpsi sebesar 5,7\%. Pola yang sama terjadi pada Zeolit $15 \mathrm{~g}$ dan Zeolit 20 g yaitu kapasitas dan waktu adsorpsi meningkat seiring dengan peningkatan jumlah adsorben yang digunakan, namun terjadi penurunan pada Zeolit $30 \mathrm{~g}$. Pengaruh penambahan adsorben terhadap pola adsorpsi yang terjadi tampak pada diagram Gambar 9 di bawah ini.

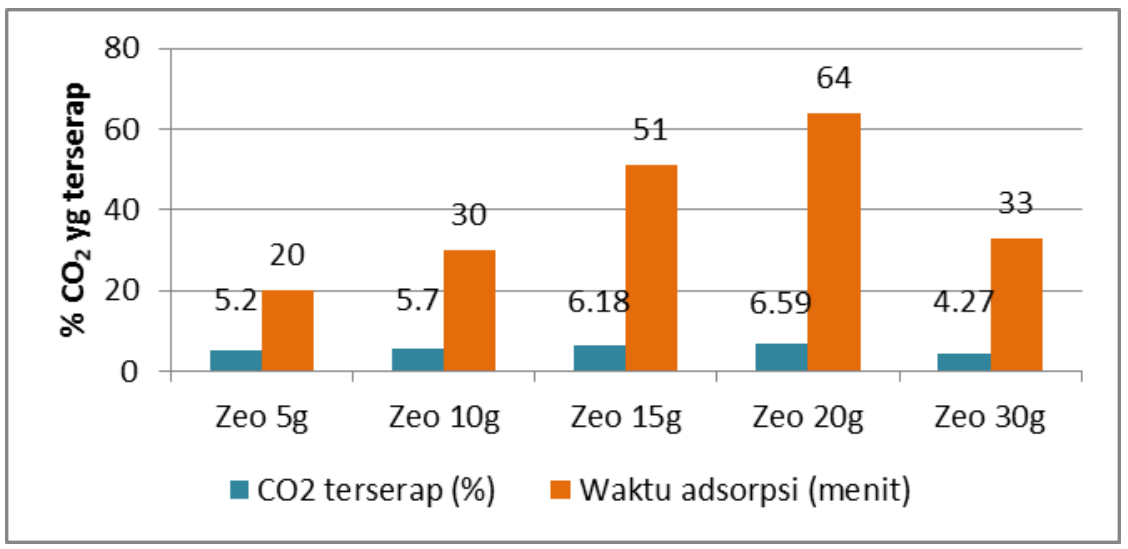

Gambar 9. Pengaruh penambahan berat adsorben zeolit X terhadap kapasitas adsorpsi gas $\mathrm{CO}_{2}$ dan waktu adsorpsi yang dibutuhkan 
Pada diagram di atas tampak bahwa secara umum semakin banyak jumlah zeolit yang digunakan sebagai adsorben maka kapasitas adsorpsi penyerapan gas $\mathrm{CO}_{2}$ semakin meningkat namun dibutuhkan waktu yang lebih lama untuk menuntaskan proses adsorpsi tersebut (tampak pada diagram blok Zeo 5g, Zeo 10g, Zeo $15 \mathrm{~g}$ dan Zeo 20g). Hal ini disebabkan bila semakin banyak jumlah adsorben yang digunakan maka peluang gas $\mathrm{CO}_{2}$ yang terperangkap di pori adsorben semakin besar dan sebagai konsekuensinya membutuhkan waktu yang lebih lama agar gas tersebut dapat terserap dengan baik.

Kondisi lain yang diamati adalah interval waktu adsorpsi selama proses. Pada perlakuan pertama dilakukan pada setiap menit (Gambar 8) sedangkan pada perlakuan kedua dilakukan tiap 2 menit (Gambar 10). Kondisi hasil adsorpsi pada interval waktu tiap 2 menit tampak pada gambar berikut:

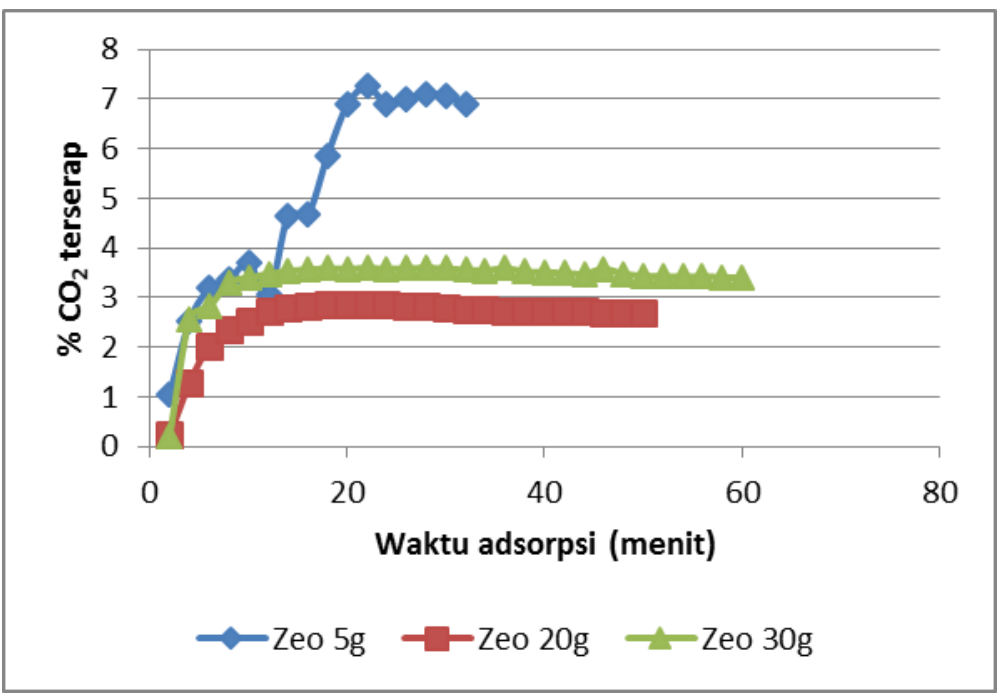

Gambar 10. Hasil adsorpsi gas $\mathrm{CO}_{2}$ menggunakan adsorben zeolit $\mathrm{X}$ pada beberapa variasi berat adsorben (interval adsorpsi tiap 2 menit)

Berdasarkan hasil di atas tampak bahwa dengan adanya perubahan mekanisme interval adsorpsi menjadi tiap dua menit sekali mengakibatkan perubahan pola adsorpsi yang cukup signifikan, khususnya pada Zeo $20 \mathrm{~g}$ dan Zeo $30 \mathrm{~g}$. Pada kurva di atas tampak pada waktu adsorpsi mencapai 10 menit kapasitas adsorpsi telah mencapai nilai maksimal dan konstan yang menandakan bahwa adsorben tidak dapat lagi menyerap gas $\mathrm{CO}_{2}$. Pengaruh perbedaan waktu interval adsorpsi terhadap \% $\mathrm{CO}_{2}$ yang terserap pada adsorben Zeo $5 \mathrm{~g}, 20 \mathrm{~g}$ dan $30 \mathrm{~g}$ tampak pada diagram Gambar 11 di bawah ini.

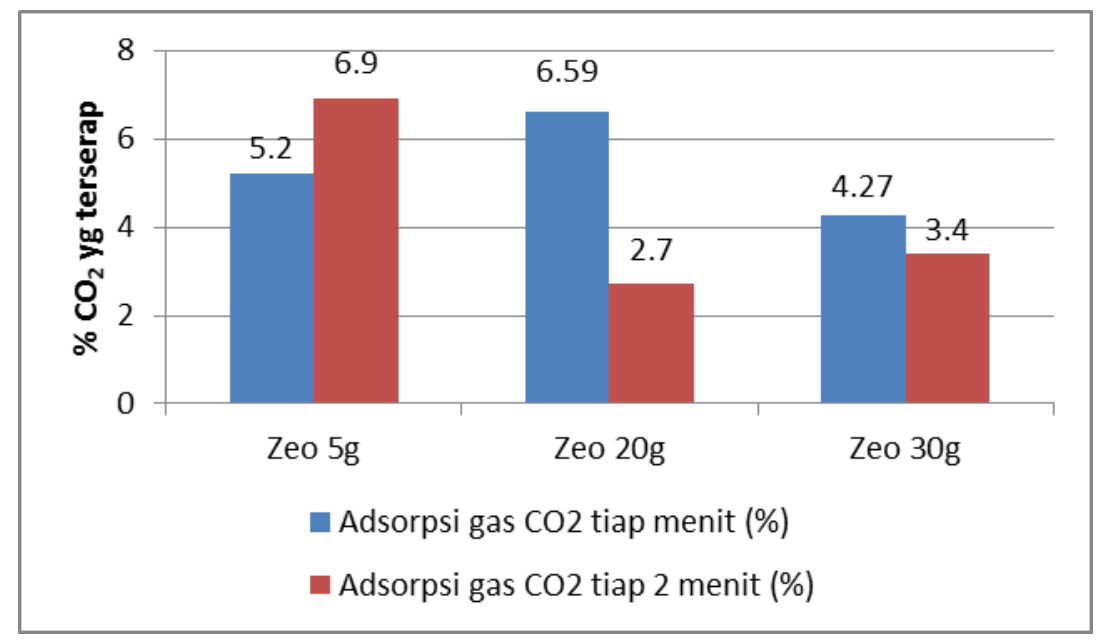

Gambar 11. Pengaruh perbedaan waktu interval adsorpsi terhadap $\% \mathrm{CO}_{2}$ yang terserap pada adsorben zeolit X 
Pada penelitian berikutnya adalah pengujian adsorpsi gas $\mathrm{CO}_{2}$ menggunakan adsorben mineral serpentin alam yang telah diaktivasi, dengan variasi jumlah/berat serpentin yang digunakan. Hasil adsorpsi tampak pada Gambar 12 di bawah ini.

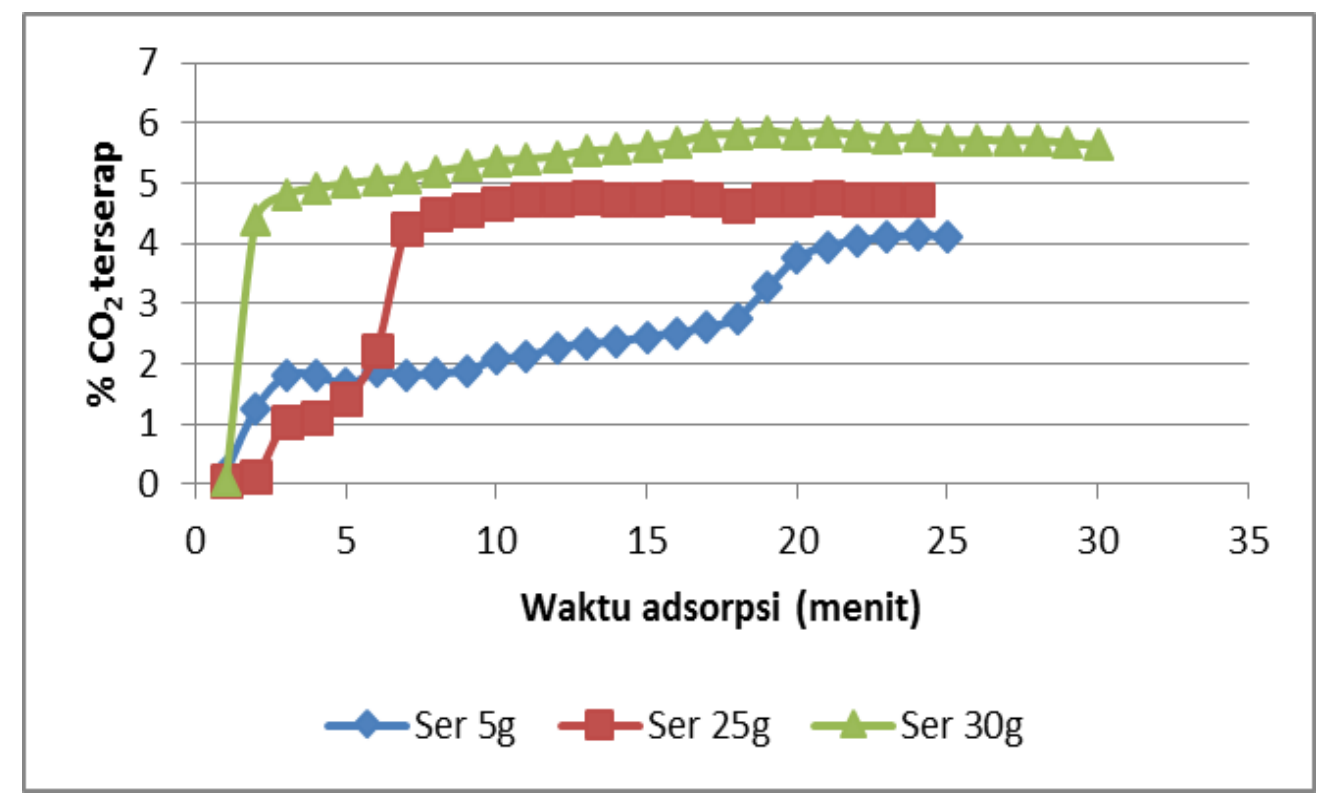

Gambar 12. Hasil adsorpsi gas $\mathrm{CO}_{2}$ menggunakan adsorben serpentin pada beberapa variasi berat adsorben (interval adsorpsi tiap 1 menit)

Pada kurva di atas tampak bahwa pola adsorpsi gas $\mathrm{CO}_{2}$ menggunakan adsorben serpentin secara umum sama dengan menggunakan adsorben zeolit, yaitu semakin banyak adsorben yang digunakan maka semakin banyak pula gas $\mathrm{CO}_{2}$ yang dapat diserap. Perbedaan yang terjadi adalah kemampuan kedua adsorben tersebut dalam mengadsorp gas $\mathrm{CO}_{2}$ pada jumlah tertentu. Perbandingan kapasitas adsorpsi pada kedua adsorben tersebut tampak pada diagram Gambar 13 di bawah ini.

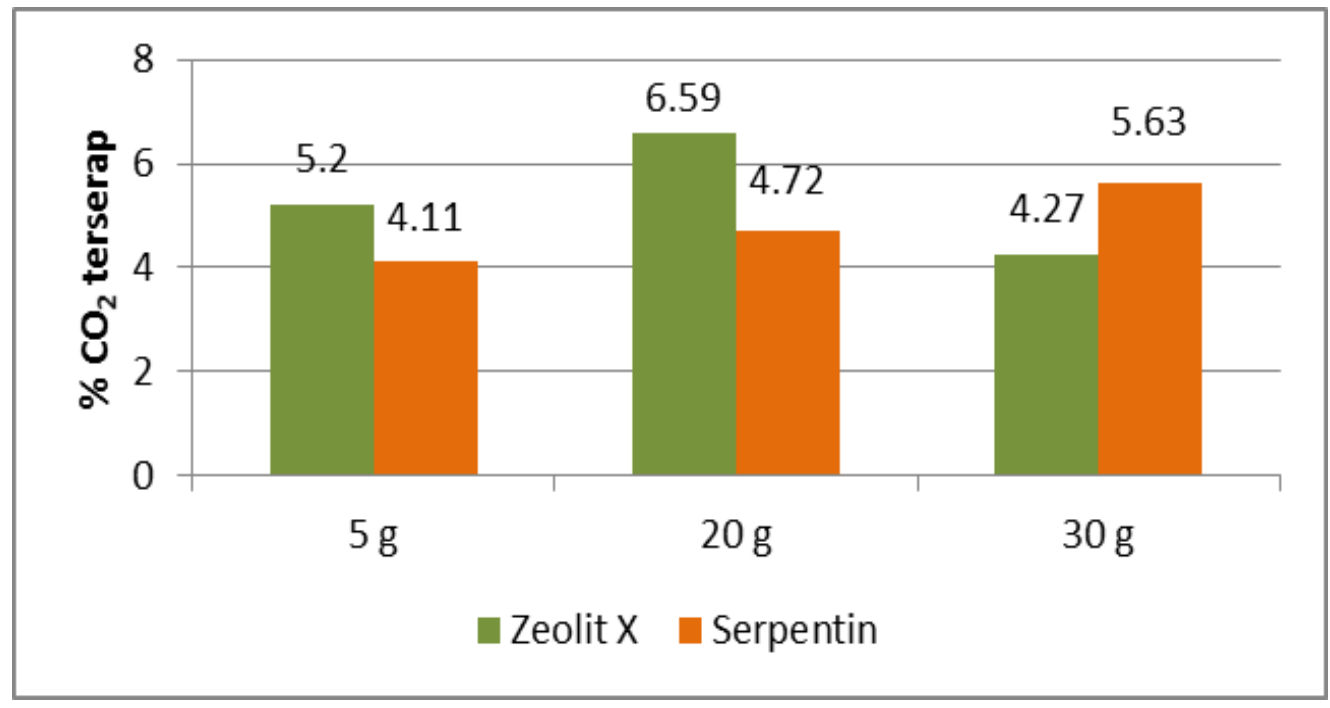

Gambar 13. Perbandingan kapasitas adsorpsi gas $\mathrm{CO}_{2}$ pada zeolit dan serpentin pada beberapa variasi berat adsorben yang digunakan 
Pada diagram di atas tampak bahwa secara umum kapasitas adsorpsi zeolit lebih tinggi sekitar $25-40 \%$ dibandingkan serpentin. Namun demikian, kapasitas adsorpsi zeolit mengalami puncaknya pada penggunaan 20 g dan kemudian menurun pada 30 g. Sedangkan serpentin, kapasitas adsorpsinya tampak meningkat hingga penggunaan $30 \mathrm{~g}$ (Gambar 14) dan mungkin akan terus meningkat hingga titik tertentu (belum dilakukan uji coba pada jumlah/berat yang lebih banyak).

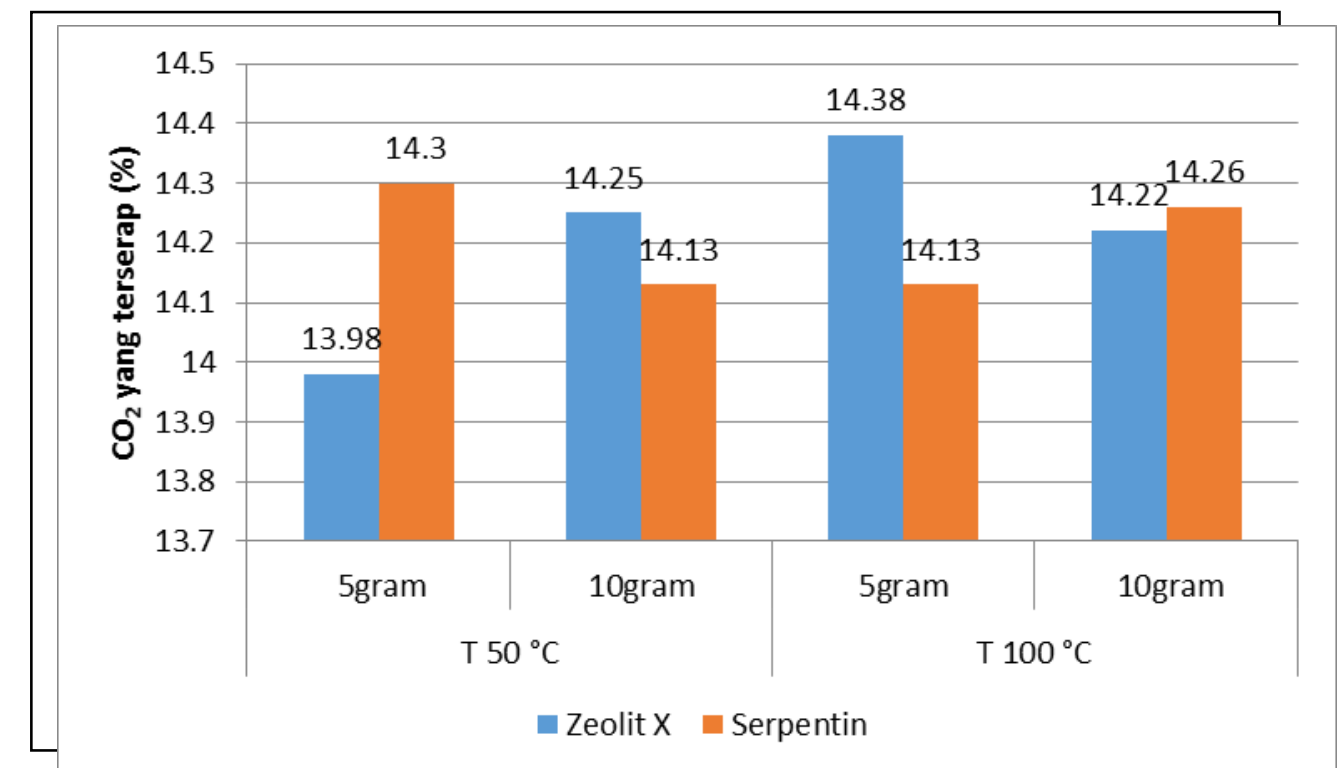

Gambar 14. Perbandingan kapasitas adsorpsi gas $\mathrm{CO}_{2}(\%)$ pada zeolit dan serpentin dengan variasi suhu gas

Diagram diatas menggunakan variasi suhu dengan memakai oven pada keluaran gas $\mathrm{CO}_{2}$ sintetis, hal ini dilakukan agar suhu gas mendekati keadaan sebenarnya di cerobong industri. Secara umum terlihat bahwa $\mathrm{CO}_{2}$ yang terserap pada zeolit $\left(50{ }^{\circ} \mathrm{C}\right)$ mengalami peningkatan dari $13.98 \%$ menjadi $14.25 \%$ seiring dengan bertambahnya jumlah zeolit, walaupun kemudian terjadi penurunan yang tidak begitu signifikan pada suhu $100{ }^{\circ} \mathrm{C}$. Sama halnya dengan serpentin, $\mathrm{CO}_{2}$ yang terserap pada suhu $50{ }^{\circ} \mathrm{C}$ hanya sedikit mengalami penurunan dari 14.3 $\%$ menjadi $14.13 \%$ dan tampak meningkat pada suhu $100{ }^{\circ} \mathrm{C}$ dari $14.13 \%$ menjadi $14.26 \%$. Pada suhu yang semakin tinggi seharusnya ruang pori pada adsorben semakin besar sehingga $\mathrm{CO}_{2}$ yang terserap lebih banyak. Namun yang terjadi di sini terjadi penurunan yang tidak begitu signifikan pada zeolit, hal ini mungkin karena pada berat sampel $10 \mathrm{~g}$ ruang porinya sedikit berkurang dari berat sampel $5 \mathrm{~g}$ sehingga $\mathrm{CO}_{2}$ yang terserap lebih sedikit. Sedangkan Serpentin pada suhu $50{ }^{\circ} \mathrm{C}$ mengalami penurunan karena adanya pengaruh unsur besi oksida (Fe) yang belum sempurna terlepas seluruhnya dari mineral serpentin, sehingga sedikitnya dapat mengganggu aplikasi mineral serpentin dalam mengikat $\mathrm{CO}_{2}$. 


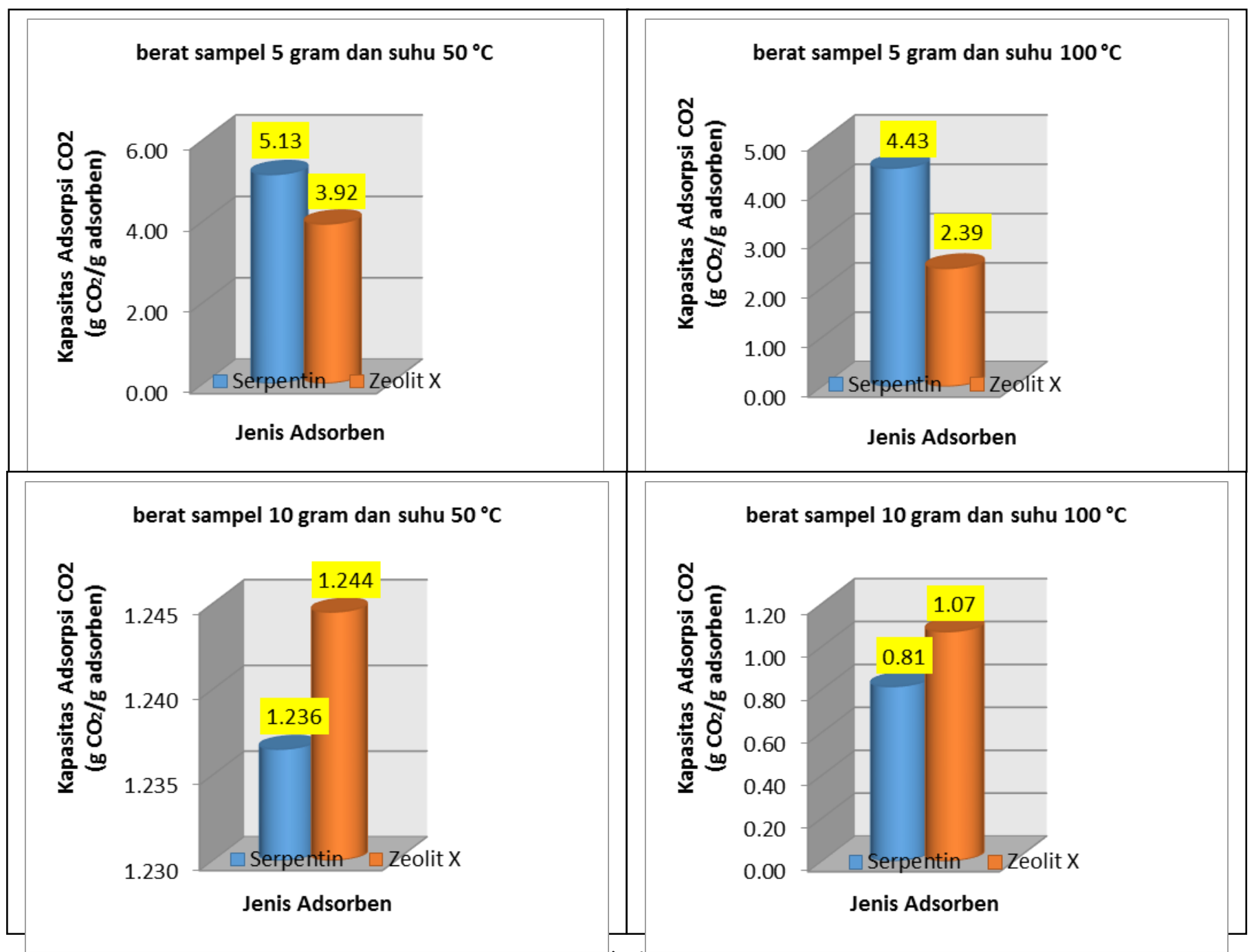

Gambar 15. Grat1k Hubungan Antara Jenis Adsorben (Serpentın dan Zeolit X) Terhadap Kapasitas Adsorpsi

Pada gambar 15 terlihat bahwa kapasitas adsorpsi tertinggi terdapat pada kondisi berat serpentin dan zeolit 5 gram di suhu $50{ }^{\circ} \mathrm{C}$ masing-masing sebesar $5.13 \mathrm{~g} \mathrm{CO}_{2} / \mathrm{g}$ serpentin dan $3.92 \mathrm{~g} \mathrm{CO}_{2} / \mathrm{g}$ zeolit. Hal ini mungkin terjadi karena pada berat adsorben 5 gram terdapat banyak pori atau ruang yang memungkinkan gas $\mathrm{CO}_{2}$ terserap dengan baik. Namun demikian masih perlu dilakukan uji coba pada jumlah/berat adsorben yang lebih banyak untuk mengetahui kapasitas adsorpsi optimum adsorben, baik zeolit maupun serpentin.

\section{KESIMPULAN DAN SARAN}

Dari uji adsorpsi ini, zeolit dan serpentin sama-sama memiliki kemampuan daya serap terhadap gas $\mathrm{CO}_{2}$ yang baik, namun serpentin memiliki kemampuan daya serap yang lebih tinggi dibandingkan dengan zeolit. Daya serap serpentin terhadap gas $\mathrm{CO}_{2}$ mencapai nilai tertinggi sebesar $14.3 \%$ (5.13 g/g), sedangkan zeolit NaX hanya mencapai $13.98 \%$ (3.92 g/g) yang masing-masing adsorben beratnya 5 gram dan suhu keluaran gas $\mathrm{CO}_{2} 50{ }^{\circ} \mathrm{C}$ dengan berat dan keluaran suhu yang sama. Berdasarkan hasil evaluasi terhadap kegiatan yang telah dilakukan, dapat disarankan hal berikut ini:

$>$ Masih perlu dilakukan uji coba pada jumlah/berat adsorben yang lebih banyak untuk mengetahui kapasitas adsorpsi optimum adsorben, baik zeolit maupun serpentin. 
$>$ Perlu dilakukan penelitian lebih lanjut mengenai struktur pori serpentin dan zeolit yang digunakan sehingga dapat diperoleh gambaran yang komprehensif mengenai hubungan antara struktur pori adsorben dengan kapasitas adsorpsinya.

$>$ Penting untuk mencari alternatif bahan material adsorben lainnya dengan memperhatikan pengaruh-pengaruh yang akan memperbesar nilai kapasitas adsorpsi.

\section{DAFTAR PUSTAKA}

Ah Hyung Alissa Park and Liang Shih Fan, 2004. CO2 Mineral Sequestration : Physically Activated Dissolution of Serpentin and pH Swing Process. Chemical Engineering Science 59 (2004) 5241-5247

Chong, S., Drese, J. H. And Jones, C. W. 2009. Adsorbent Materials for Carbon Dioxide Capture from Large Anthropogenic Poin Sources. ChemSusChem 2: 796-854

Daniel J Fauth and Yee Soong, 2001. Mineral Sequestration Utilizing Industrial By-Products, Residus, and Minerals. NETL (National Energy Technology Laboratory) Pitsburrgh PA, 15236-0940

Green, D.A., B.S. Turk, R.P. Gupta, J.W. Portzer, W.J. McMichael, and D.P. Harrison, 2002. Capture of Carbon Dioxide from flue gas using regenerable sorbents. 19th Annual International Pittsburgh Coal Conference. September 23-27, Pittsburgh, Pennsylvania, USA

Hoffman, J.S., D.J. Fauth., and H.W. Pennline, 2002. Development of novel dry regenerable sorbents for CO2 capture. 19th Annual International Pittsburgh Coal Conference. September 23-27, 2002 Pittsburgh, Pennsylvania, USA.

IPCC, 2006., Capture of CO2, IPCC Special Report Carbon Dioxide Capture and Storage, diakses 31 Desember 2008. http:/ / www.luminatellc.com/Newsletter\%20PDFs/CO2\%20Part\%203.pdf

Ishibasi et all, 1999, Study On CO2 Removal Technology from Flue Gas of Thermal Power Plan by Combined Systems with Pressure Swing Adsorption and Super Cold Separator, Shizuoka University

M. Mercedes Maroto Valer1, Mattew E. Kuchta1, Yinzi Zhang1, Jhon M Andresen1, Daniel J. Faut2, 2005. Comparason of Physical and Chemical Activation of Serpentine for Enhanced CO2 Sequestration.1The Energy Institute and Department of Energy and Geo-Enviromental Engineering, The Pensylvania State University, University Park, PA 16802 and 2U.S. Deparment of Energy, National Energy Technology Laboratory, Pittsburgh 15236

Nakagawa, K., T. Ohashi 1998: A novel method of CO2 capture from high temperature gases, Journal Electrochem. Soc., 145(4): 1344-1346

PEUI, 2006. Indonesia Energy Outlooks and Statistics, 2006

Roza Adriany, dkk, 2011. Pembuatan Aditif Combustion Booster dan Pack Kolom untuk mengurangi Emisi CO dan CO2 pada Kendaraan Bermotor. Puslitbang Lemigas, Jakarta

Rodhie Saputra, 23 Januari 2006. Pemanfaatan Zeolit Sintetis Sebagai Alternatif Pengolahan Limbah Industri. warmada.staff.ugm.ac.id/Articles/rodhie-zeolit.pdf

Ron Zevenhoven, Jens Kohlmann, 2001.Direct Dry Mineral Carbonation for CO2 Emissions Reduction in Finland. Helsinki University of Technology, Laboratory for Energy Engineering and Enviromental Protection

Sander, M.T. and C.L. Mariz, 1992, The Fluor Daniel Econamine FG Process: Past Experiance and Present Day Focus,"Energy Conversion and Management"

Sircar, S., C.M.A. Golden, 2001: PSA process for removal of bulk carbon dioxide from a wet hightemperature gas. US Patent No. 6322612.

Subho Choi, Jeffrey H. Drese, and Christopher W. Jones., 2009. Adsorbent Materials for Carbon Dioxide Capture from Large Anthropogenic Point Sources. ChemSusChem 2, 796-854. WileyVCH Verlag Gmbh\&Co. KGaA, Weinheim.

http://www3.interscience.wiley.com/cgi-bin/fulltext/122589165/PDFSTART

Thomas M. Kerr, 2005. Legal Aspects of Storing CO2 : Update and Recommendations, International Energy Agency (IEA), 2007, p.15-16

Toni Samiaji, 2009. Upaya Memgurangi CO2 di Atmosfer, Berita Dirgantara, Vol. 10, No. 3, Lapan, September 2009, Jakarta

Toni Samiaji, 2010. Sebaran Emisi Gas CO2 di Indonesia, Proseding Seminar Penerbangan dan Antariksa 2010, Lapan

W.J.J. Huijgen \& R.N.J. Comans, 2003. Carbon Dioxcide Sequestration By Mineral Carbonation. ECN-C-03-016 
Yokoyama, T., 2003. Japanese R \& D on CO2 Capture. Greenhouse Gas Control Technologies, Proc of the 6th International Conference on Greenhouse Gas Control Technologies (GHGT-6), 1-4 Oct 2002, Kyoto, Japan, J. Gale and Y. Kaya (eds), Elsevier Science Ltd, Oxford, UK. 18-18

Yoo, Kyoungkeun et Al, 2009. Dissolution of Magnesium from Serpentine Mineral in Sulfuric Acid Solution. Minerals \& Materials Processing Division, Korea Institute of Geoscience \& Mineral Resources (KIGAM), Daejeon 305-350, Korea 